\title{
Pemberdayaan Kelompok Pra-Produktif Simplisia Herbal Melalui Pembuatan Simplisia Jeruk Lemon untuk Meningkatkan Imunitas Tubuh di Masa Pandemi Covid-19
}

\author{
IP Darmawijaya ${ }^{1 *}$, Putu Chris Susanto ${ }^{2}$ dan Dylla Hanggaeni Puspaningrum ${ }^{2}$ \\ ${ }^{1}$ Fakultas Kesehatan, Sains, dan Teknologi, Universitas Dhyana Pura, Jl. Raya Padang Luwih, Dalung, Kuta \\ Utara, Dalung, Kec. Kuta Utara, Kabupaten Badung, Bali 80351 \\ ${ }^{2}$ Fakultas Ekonomika, Bisnis, dan Humaniora, Universitas Dhyana Pura, Jl. Raya Padang Luwih, Dalung, \\ Kuta Utara, Dalung, Kec. Kuta Utara, Kabupaten Badung, Bali 80351
}

Correspondence: darmawijaya@undhirabali.ac.id

Received: 30 Juni 2021 - Revised: 01 Agustus 2021 - Accepted: 16 Agustus 2021

\begin{abstract}
Abstrak. Potensi keindahan alam yang dimiliki oleh Desa Catur adalah topografi daerah yang berbukit-bukit dan secara agraris, diapit oleh empat pegunungan yaitu pegunungan Penulisan, Pegunungan Batur, Pengunungan Catur, dan Pegunungan Puncak Mangu. Hasil panen jeruk lemon di Desa Catur yang sangat melimpah menyebabkan harga jual menjadi sangat anjlok sehingga merugikan para petani jeruk lemon. Dengan anjloknya harga jeruk lemon pada musim panen menyebabkan para petani membiarkan jeruk lemon mereka terbuang secara percuma. Penyebabnya adalah kurangnya pengetahuan dan keterampilan warga desa dalam mengolah pasca panen buah jeruk lemon ini. Kegiatan pengabdian masyarakat ini diikuti oleh ibu-ibu yang tergabung dalam kelompok Pra-Produktif Simplisia Herbal yang merupakan perkumpulan ibu-ibu PKK PKK Desa Catur-Kintamani Kabupaten Bangli yang tergabung dalam UP2K (Unit Peningkatan Pendapatan Keluarga). Kegiatan yang dilakukan yaitu Penyuluhan, pelatihan, dan pemasaran. Hasil dari kegiatan ini adalah ada peningkatan nilai rerata pretest sebesar 20 menjadi nilai postest sebesar 95. Produk simplisia buah jeruk lemon yang dihasilkan ini telah dikemas dan dipasarkan melalui media sosial.
\end{abstract}

Kata kunci: Simplisia, buah jeruk lemon, Desa Catur, UP2K, kelompok pra-produktif

Citation Format: Darmawijaya, I.P., Susanto, P.C., \& Puspaningrum, D.H.. (2021). Pemberdayaan Kelompok Pra-Produktif Simplisia Herbal Melalui Pembuatan Simplisia Jeruk Lemon Untuk Meningkatkan Imunitas Tubuh di Masa Pandemi Covid-19. Prosiding Seminar Nasional Abdimas Ma Chung (SENAM), 411-419. 


\section{PENDAHULUAN}

Desa Catur, Kecamatan Kintamani, Kabupaten Bangli terletak $65 \mathrm{~km}$ dari pusat Kota Denpasar dengan waktu tempuh 1 jam 40 menit. Potensi keindahan alam yang dimiliki oleh Desa Catur adalah topografi daerah yang berbukit-bukit dan secara agraris, diapit oleh empat pegunungan yaitu pegunungan Penulisan, Pegunungan Batur, Pengunungan Catur, dan Pegunungan Puncak Mangu. Suhu udara yang dimiliki juga sangat sejuk sehingga sangat cocok untuk perkebunan kopi arabika serta berbagai macam sayuran dan buah seperti jeruk lemon. Hasil panen jeruk lemon di Desa Catur yang sangat melimpah menyebabkan harga jual menjadi sangat anjlok sehingga merugikan para petani jeruk lemon. Dengan anjloknya harga jeruk lemon pada musim panen menyebabkan para petani membiarkan jeruk lemon mereka terbuang secara percuma. Seperti diketahui bahwa jeruk lemon memiliki kandungan antioksidan yang sangat tinggi.

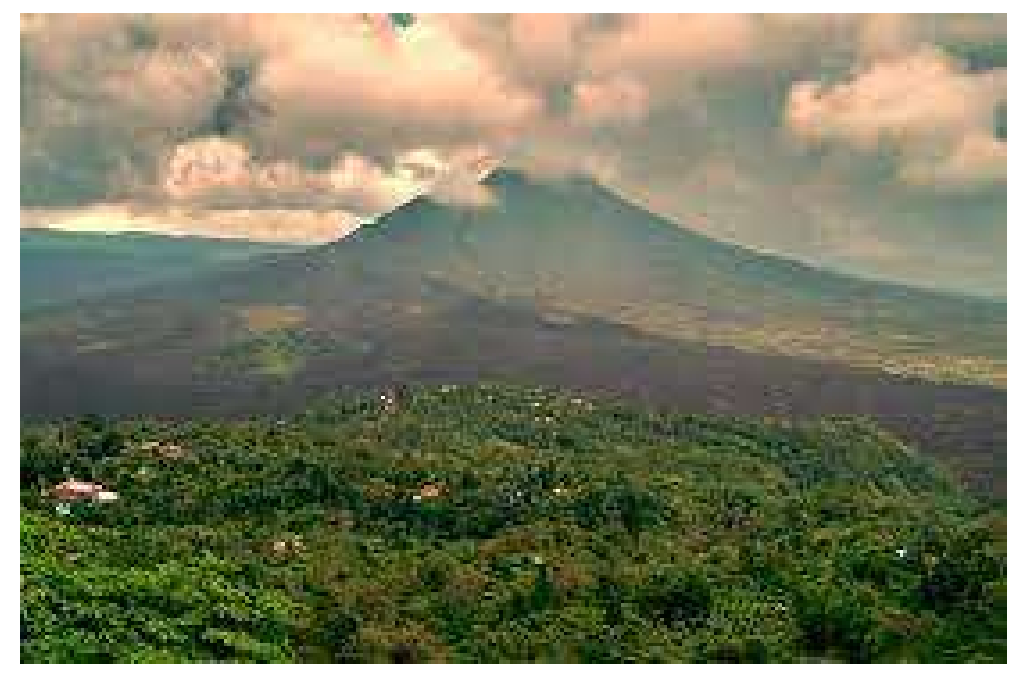

Gambar 1. Keindahan Alam Desa Catur

Dalam dua tahun terakhir menjaga dan meningkatkan imunitas tubuh menjadi salah satu yang sangat diperlukan. Mengingat wabah pandemi Coronavirus Disease 19 atau Covid-19 menjadi pandemi global yang telah dinyatakan oleh World Health Organization (WHO). Kandungan antioksidan yang terdapat dalam buah jeruk lemon diketahui dapat membantu dalam meningkatkan imunitas tubuh dari bakteri dan virus berbahaya. Meskupun buah jeruk lemon ini banyak memiliki manfaat, namun warga Desa Catur belum mampu mengolah pasca panen buah jeruk lemon ini. Penyebabnya adalah kurangnya pengetahuan dan keterampilan warga desa dalam mengolah pasca panen buah jeruk lemon ini. 
Oleh karena itu, kegiatan pengabdian masyarakat yang dilakukan yaitu pelatihan pembuatan simplisia jeruk lemon untuk meningkatkan motivasi warga Desa Catur dalam diversifikasi produk simplisia jeruk lemon. Mengingat permintaan akan simplisia jeruk lemon meningkatkan pada masa pandemi Covid-19 ini. Tujuan pelaksanaan kegiatan pengabdian masyarakat ini adalah untuk membuat produk simplisia jeruk lemon yang sangat bermanfaat bagi kesehatan serta menumbuhkan jiwa kewirausahaan bagi warga desa.

\section{MASALAH}

Belum maksimalnya pengolahan pasca panen buah jeruk lemon di masa pandemi Covid-19. Warga desa belum memiliki pengetahuan tentang khasiat dari buah jeruk lemon dalam meningkatkan imunitas tubuh. Belum memiliki keterampilan dalam mengolah dan mengemas produk simplisia buah jeruk lemon untuk menjadi produk yang bisa dijual ke pasaran.

\section{METODE PELAKSANAAN}

Kegiatan pengabdian masyarakat ini diikuti oleh ibu-ibu yang tergabung dalam kelompok Pra-Produktif Simplisia Herbal yang merupakan perkumpulan ibu-ibu PKK PKK Desa Catur-Kintamani Kabupaten Bangli yang tergabung dalam UP2K (Unit Peningkatan Pendapatan Keluarga). Melalui kegiatan ini, mitra pengabdian memiliki pengetahuan pengolahan produk pasca panen buah jeruk lemon. Oleh karena itu, perlu diberikan pengetahuan terkait dengan pengolahan produk buah lemon serta dilanjutkan dengan pelatihan dan pendampingan. Kegiatan Pengabdian Masyarakat ini dilaksanakan di Desa Catur, Kecamatan Kintamani, Kabupaten Bangli dalam kurun waktu Bulan Mei-Juli Tahun 2021.

a. Pra Kegiatan: Pada tahap ini kegiatan yang dilakukana adalah: 1) melakukan observasi ke lokasi kegiatan dan melaksanakan pertemuan dengan Kepala Desa Catur dan Ketua Tim penggerak PKK Desa Catur; 2) menjelasakan langkah-langkah dalam pembuatan simplisia buah jeruk lemon; 3) perancangan label kemasan produk simplisia buah jeruk lemon.

b. Pelaksanaan Kegiatan: pada tahap ini kegiatan yang dilakukan adalah: 1) memberikan penyuluhan tentang khasiat dan manfaat dari buah jeruk lemon; 2) memberikan pelatihan dalam pembuatan produk simplisia buah jeruk lemon; 3) memberikan 
pelatihan dalam pengemasan produk; 4) Pemasaran produk simplisia buah jeruk lemon.

c. Evaluasi Hasil Kegiatan: evaluasi yang dilakukan terhadap kegiatan pengabdian masyarakat yang telah dilaksanakan adalah melihat keberlangsungan kegiatan dan manfaat yang diperoleh.

\section{HASIL DAN PEMBAHASAN}

Kegiatan pengabdian masyarakat ini dilaksanakan di Desa Catur, Kecamatan Kintamani, Kabupaten Bangli yang diikuti oleh Perkumpulan Ibu-Ibu Pkk Pkk Desa Catur-Kintamani Kabupaten Bangli Yang Tergabung Dalam UP2K (Unit Peningkatan Pendapatan Keluarga) dengan tahapan-tahapan sebagai berikut:

1. Penyuluhan Tentang Pengetahuan dan Konsep Dasar Simplisia Buah Jeruk Lemon Pada kegiatan ini dilaksanakan untuk mengetahui tingkat pengetahuan peserta kegiatan terkait dengan pengetahuan dan konsep dasar simplisia buah jeruk lemon.

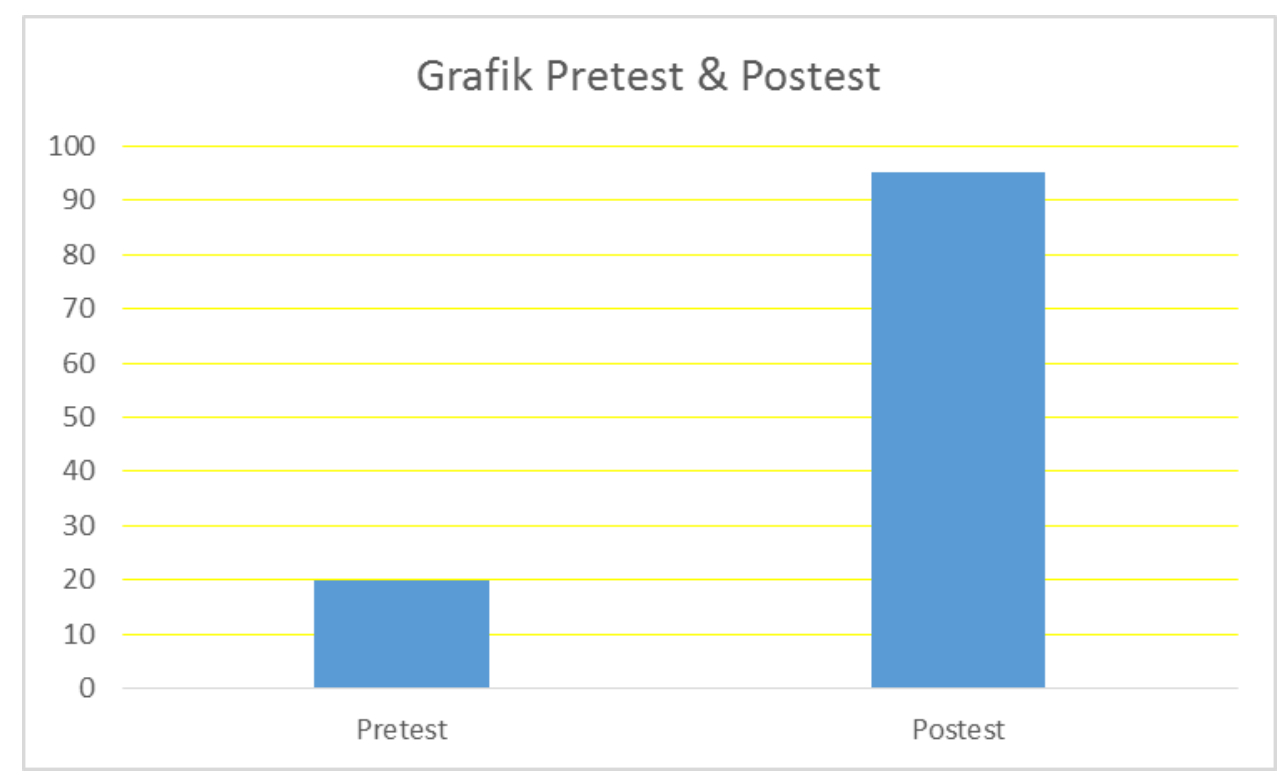

Gambar 2. Grafik Peningkatan Nilai Pretest Dan Postest

Kegiatan dilaksanakan dengan pengisian kuisioner pretest dan postest. Dari hasil pengisian kuisioner didapatkan hasil bahwa terjadi peningkatan nilai rerata pretest sebesar 20 menjadi nilai rerata postest sebesar 95 disajikan pada Gambar 2. Dari hasil ini menunjukkan bahwa dengan kegiatan penyuluhan memberikan dampak yang besar dalam peningkatan pengetahuan dan konsep dasar simplisia buah jeruk lemon. 


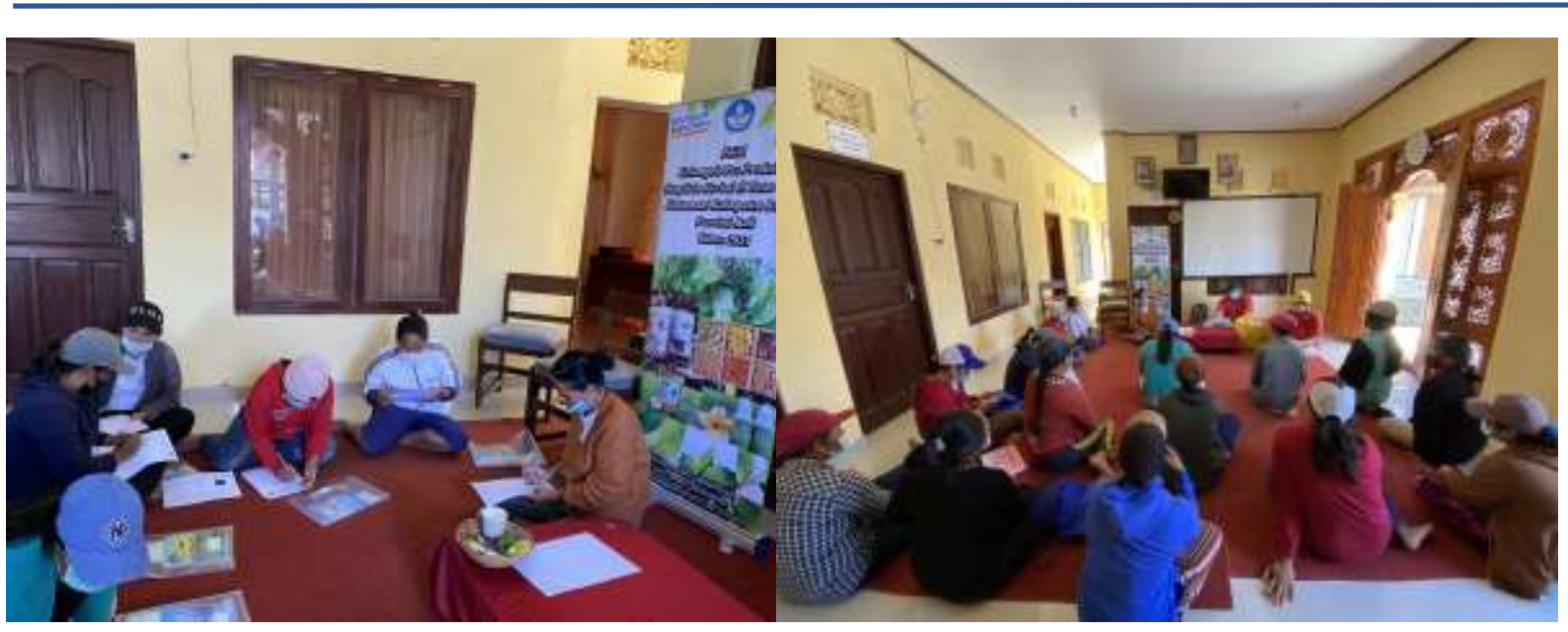

(a)

(b)

Gambar 3. (a) Kegiatan Pretest; (b) Kegiatan Penyuluhan

2. Pelatihan Pembuatan Simplisia Buah Jeruk Lemon

Pada tahap ini dilaksanakan kegiatan pealtihan cara pembuatan simplisia buah jeruk lemon. Para peserta sangat antusias sekali mengikuti kegiatan mengingat selama ini mereka menjualnya hanya buah segar saja. Dalam kegiatan ini narasumber menjelaskan cara-cara pembuatan yaitu: (a) buah lemon segar hasil panen dicuci bersih dengan tujuan untuk menghilangkan kotoran-kotoran yang menempel pada kulit buah lemon; (b) setelah dicuci, buah lemon ditiriskan; (c) selanjutnya buah lemon diiris secara dengan ketebalan tidak terlalu besar atau iris tipis; (d) setelah semua lemon diiris, kemudia dikeringkan dengan menggunakan alat pengering dengan suhu pengeringan 55 derajat celsius dengan waktu pengeringan 5 jam; (e) setelah buah lemon kering lalu dikeluarkan dari mesin pengering; (f) simplisia buah jeruk lemon siap untuk dikemas.

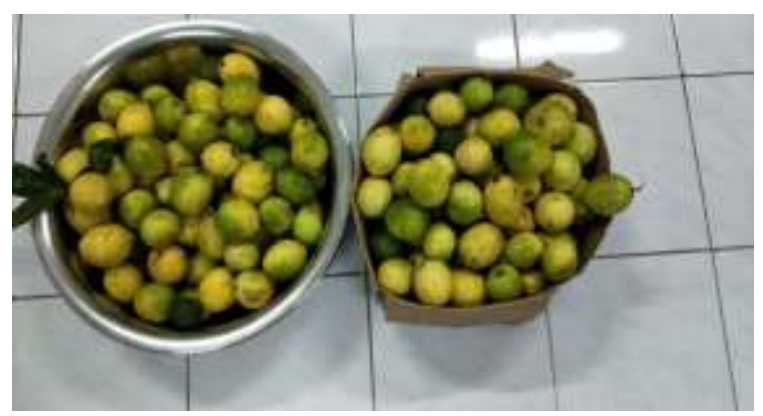

Gambar 4. Hasil Panen Buah Jeruk Lemon 


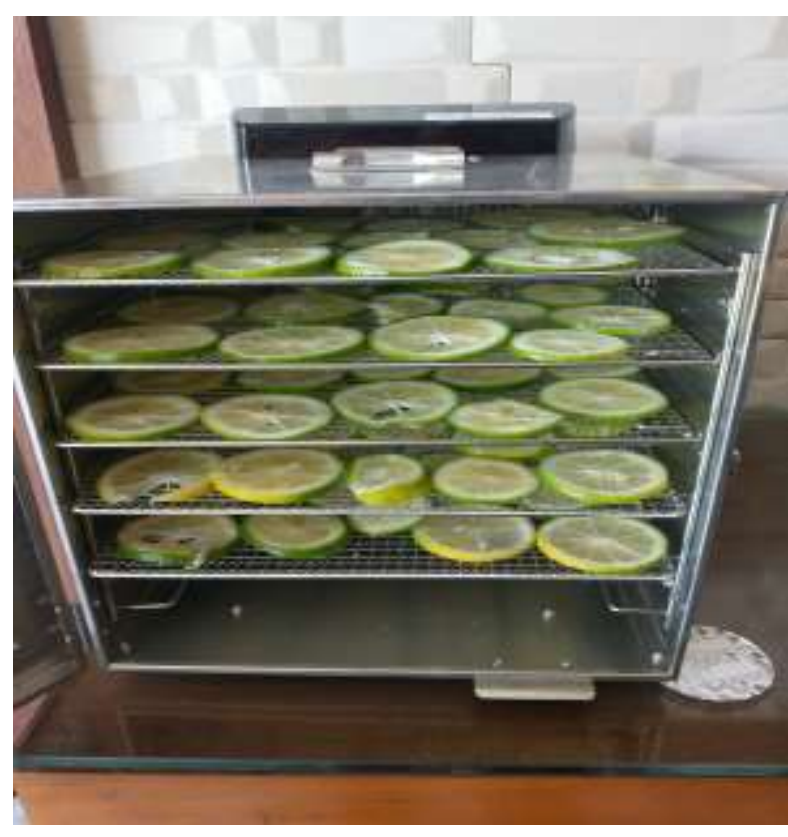

Gambar 5. Irisan Lemon Dalam Mesin Pengering

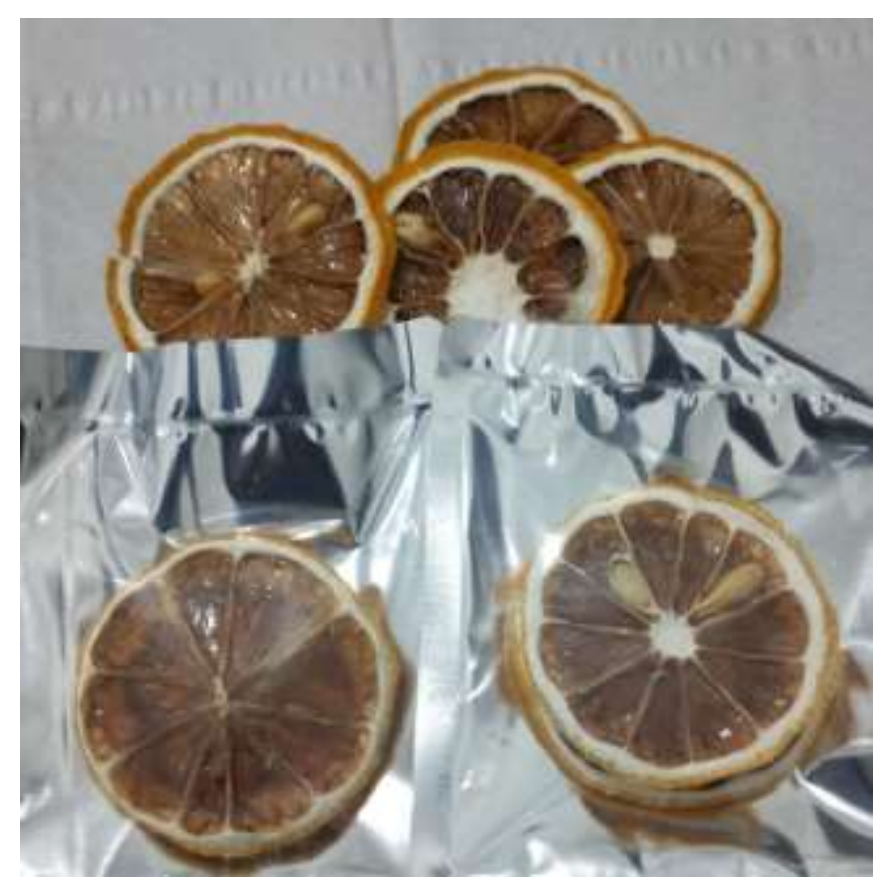

Gambar 6. Buah Lemon Yang Sudah Kering

3. Pelatihan Pengemasan Produk

Untuk menarik konsumen terhadap produk yang dihasilkan, diperlukan sebuah kemasan dengan label yang menarik. Kemasan merupakan sejenis wadah atau tempat untuk menyimpan produk agar tahan lama dan tidak bereaksi dengan udara luar. 
Seiring dengan perkembangan jaman, kemasana juga dapat digunakan sebagai media promosi dalam memperkenalkan produk dengan tujuan untuk menarik konsumen.

Kemasan produk simplisia buah jeruk lemon adalah kemasan pounch dengan isian produk sebanyak 10 sachet. Untuk produk simplisia buah jeruk lemon yang dikemas diberi label produk dengan nama : "Minuman Herba-Lemon Tea". Terhadap produk simplisia buah jeruk lemon yang sudah dikemas kemudian siap untuk dipasarkan.

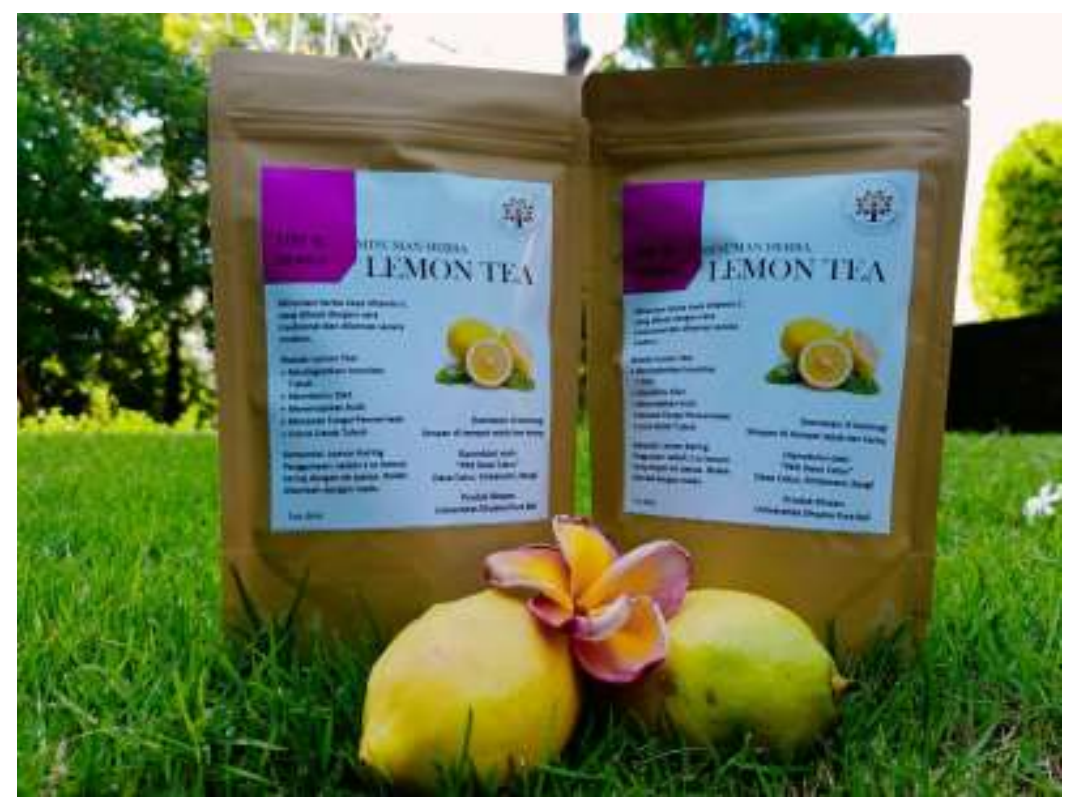

Gambar 7. Simplisia Buah Jeruk Lemon Yang Telah Dikemas

4. Pendampingan Pemasaran Produk

Terhadap produk yang telah dihasilkan kemudian dipasarkan ke masyarakat. Pemasaran yang dilakukan yaitu memasarkan ke lingkungan sekitar, mengikuti pameran produk, kemudian memperkenalkan produk melalui media sosial seperti instagram dan facebook. Dari hasil pemasaran ini didapatkan bahwa masyarakat sangat terbantu sekali dengan adanya produk ini karena dimasa pandemi covid-19 ini masyarakat memerlukan suatu minuman sehat yang dapat meningkatkan imunitas tubuh. Bapak I Wayan Sukarata selaku Kepala Desa Catur sangat berterimakasih kepada tim pelaksana pengabdian karena telah mengajarkan kepada warganya terutama ibu-ibu kelompok pra-produktif simplisia herbal car pembuatan produk ini, semoga dengan dipasarkannya produk ini dapat menambah income dari warga Desa Catur Kintamani Kabupaten Bangli. 


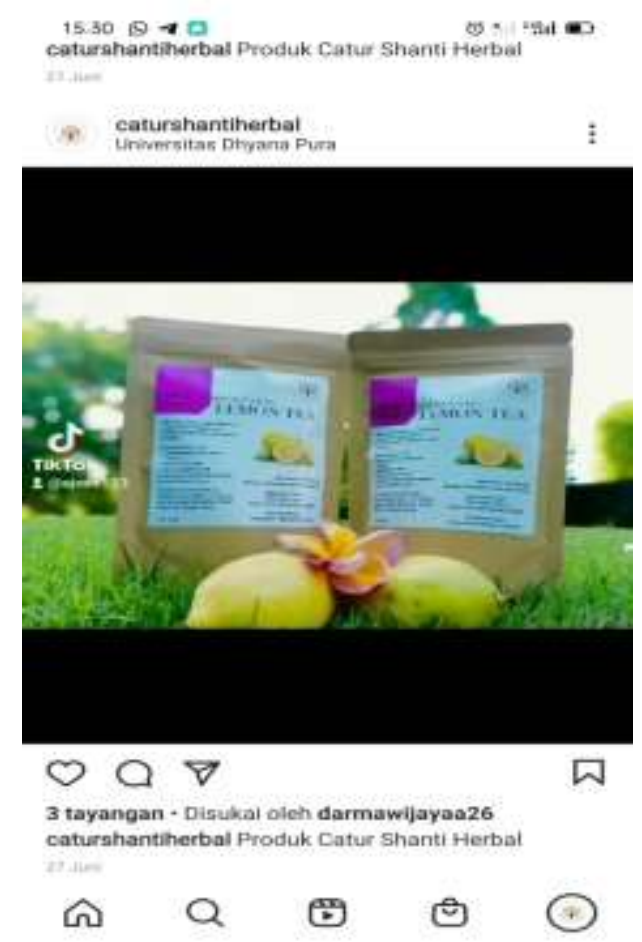

Gambar 8. Salah Satu Pemasaran Di Media Sosial

\section{KESIMPULAN}

Kegiatan pengabdian masyarakat yang telah dilakukan berhasil meningkatkan pengetahuan dan konsep dasar tentang cara pengolahan buah jeruk lemon menjadi simplisia dengan peningkatan nilai rerata pretest dan postest. Produk yang telah dihasilkan ini telah dipasarkan melalui mengikuti pameran-pameran dan media sosial. Produk ini diharapkan mampu meningkatkan income dari masyarakat Desa Catur.

\section{UCAPAN TERIMA KASIH}

Pada kesempatan ini, penulis mengucapkan terima kasih kepada Direktorat Penelitian dan Pengabdian Masyarakat (DRPM) Kemendikbudristek RI atas pendanaan hibah yang telah diberikan. Terima kasih juga kepada Universitas Dhyana Pura Cq Lembaga Penelitian dan Pengabdian Masyarakat atas fasilitasi dalam pelaksanaan kegiatan pengabdian masyarakat ini. 


\section{(c) (i)}

(C) 2021 by authors. Content on this article is licensed under a Creative Commons Attribution 4.0 International license. (http://creativecommons.org/licenses/by/4.0/). 